\title{
A mathematical model for in-plant Milk-Run routing
}

\section{Fabrika içi Milk Run rotalama için bir matematiksel model}

\author{
Aydın SIPAHIOOGLLU ${ }^{*}$ iD İslam ALTIN ${ }^{2}$ iD \\ 1,2Department of Industrial Engineering, Eskisehir Osmangazi University, Eskisehir, Turkey. \\ asipahi@ogu.edu.tr, ialtin@ogu.edu.tr
}

Geliş Tarihi/Received: 14.06.2019, Kabul Tarihi/Accepted: 09.12.2019

doi: $10.5505 /$ pajes.2019.03366

* Yazışlan yazar/Corresponding author Special Issue Article / Özel Sayı Makalesi

\begin{abstract}
Milk-run is one of the lean logistics implementations defined as a cyclic materials delivering system. In-plant milk-run system, a variant of milkrun, runs for the delivering materials within the plant from warehouse to assembly stations in a cyclic manner. It is implemented using Automated Guided Vehicles (AGV), which provide automated materials handling in plant. In this study, in-plant milk-run system is discussed and the importance of determining milk-run routes and period is emphasized. A mixed integer mathematical model is proposed for the determination of milk-run routes and its period simultaneously for AGVs. Besides, the mathematical model allows split deliveries for assembly stations. The proposed model is coded using GAMS software and the success of this model is shown on randomly generated test problems. The proposed model obtains the optimal solution approximately in 1 second for generated two test problems. This points out the advantage and practicability of the proposed mathematical model for in-plant milk-run system.
\end{abstract}

Keywords: Logistics, In-Plant Milk-Run system, Automated guided vehicles, Mixed integer programming

\section{Introduction}

Material handling system plays a very important role in manufacturing. The objectives of material handling system are improving facility utilization, reducing unit cost of production, increasing efficiency of material flow and the usage rate of the material handling vehicles [1],[2]. Material handling should not be considered simply as moving materials [3]. Because, it can account for $30-75 \%$ of the total cost and proper material handling system can reduce a plant's operating cost by $15-30 \%$ [2]. Furthermore, material handling composes the $25 \%$ of the workers' time, $55 \%$ of the factory area and $87 \%$ of the production time [4]. Therefore, it is crucial for reducing cost and eliminating waste.

On time delivery provided by efficient material handling system is one of the objectives of lean logistics. The implementation of lean logistics provides some benefits such as balancing production line, reduction of stock levels, elimination of delays and waste in the logistics process [5]. It is the logistics applications in lean manufacturing environment and consists of three parts as in-bound logistics, out-bound logistics and inplant logistics [6]. While in-plant logistics deals with logistics in the factory, in-bound and out-bound logistics deal with obtaining raw materials and delivering goods to the customer, respectively [7]. These three types of logistics affect each other implicitly and one problem in any of them signify that there will
Öz

Milk-run döngüsel malzeme taşıma sistemi olarak yalın lojistik uygulamalarından birisidir. Milk-run'ın bir çeșidi olan fabrika içi milkrun sistemi, fabrika içinde depodan montaj istasyonlarına döngüsel bir yaklaşımla malzeme taşıması için çalıșır. Fabrika içi milk-run sistemi fabrikada malzemelerin otomatik olarak elleçlenmesini sağlayan otomatik yönlendirilmiş araçlar (OYA) kullanılarak gerçekleştirilir. $\mathrm{Bu}$ çalıșmada, fabrika içi milk-run sistemi ele alınmıș ve milk-run rotalarının ve periyodunun belirlenmesinin önemi vurgulanmıştır. OYA'ların milk-run rotalarını ve periyotlarını eş zamanlı olarak belirlemek için bir karma matematiksel model önerilmektedir. Matematiksel model aynı zamanda montaj istasyonları için bölünmüş teslimatlara izin vermektedir. Önerilen model GAMS yazılımı kullanılarak kodlanmış ve modelin bașarısı rassal olarak türetilen test problemleri üzerinde gösterilmiștir. Önerilen model, türetilen test problemlerinin en iyi çözümünü yaklaşık 1 saniye içinde elde etmiştir. Bu durum, fabrika içi milk-run sistemi için önerilen matematiksel modelin avantajını ve uygulanabilirliğini göstermektedir.

Anahtar kelimeler: Logistik, Fabrika içi Milk-Run sistemi, Otomatik yönlendirilmiş araçlar, karma tamsayılı programlama

be a problem in the others. For this reason, the logistics process should be carried out in a good way at all levels simultaneously.

Lean logistics ensure the delivery of the products at the right time to the right place and carry out these activities, effectively [8]. There is a correlation between a just in time plan and a good logistics strategy [9]. For in-plant logistics just in time material supply is a vital issue, because early material supply causes inventory holding cost and late material supply causes stopping assembly lines due to the parts shortage [10]. Milk-Run system, cyclic goods taking, is able to reduce these kind of delays in manufacturing especially in assembly lines [11]. Indeed, milkrun system can also be considered as a special kind of Vehicle Routing Problem with Time Windows [12]. Since it is actually a lean logistics method, it is possible to be implemented for all three types of lean logistics. There are two different milk-run systems as supplier milk-run and in-plant milk-run system in the literature [6]. With the supplier milk-run system, goods are collected from external suppliers and delivered to a customer by following a predefined route [13],[14]. On the other hand, inplant milk-run system helps to deliver materials from warehouse to assembly lines in plants in an easier and possibly shorter way. Moreover, unlike supplier milk-run system, it is not affected by external factors such as weather conditions. Accordingly, schedules of in-plant milk-run system are more reliable and robust [6]. The objective of in-plant milk-run system can be defined as minimizing the total inventory holding 
and transportation cost to ensure no parts shortage will occur in assembly stations.

In-plant milk-run system is widely used in automotive sector and it is also suitable for factory where mass production is made [15]. It can be implemented using Automated Guided Vehicles (AGV). AGVs use predefined paths along which they move from warehouse to destination point and it is possible to increase the capacity of AGVs with additional trailers [16]. As an example, in-plant milk-run system is shown in Figure 1 having 7 stations and single warehouse. This figure shows that demands of Station 1, Station 2 and Station 3 are satisfied by AGV 1, demands of other stations are satisfied by AGV 2.

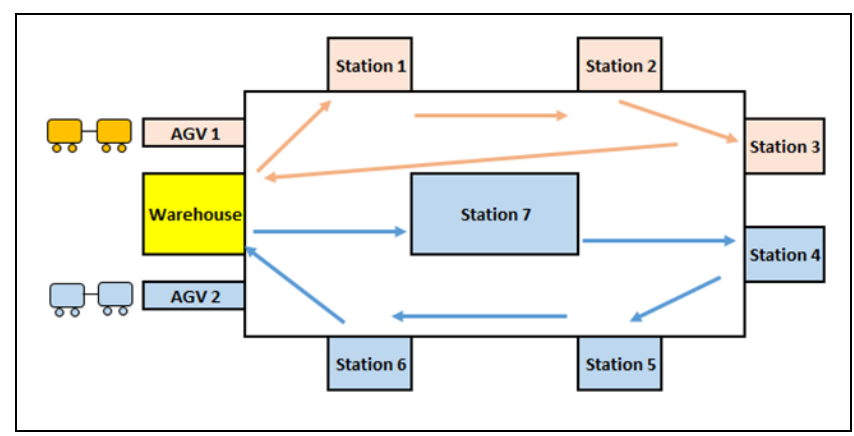

Figure 1: In-plant Milk-Run system.

In plant Milk-Run systems has some certain advantages listed below [17];

- Improved performance of the supply chain and logistics because of effective transportation,

- Lower inventory and reduced maintenance costs,

- More effective use of buffer stock area,

- More appropriate and reliable delivery times,

- Increased capital turnovers,

- Increased flexibility in supplying the parts,

- Smooth and well-established logistic operations.

As in-plant milk-run system achieves delivery by predetermined paths and time schedule, determining milk-run routes and its period is very important to improve the efficiency of the relevant system. In this system, routes and periods should be determined in terms of demands of the assembly stations, the number of vehicles and their capacities. There are few studies in the literature in order to obtain milk-run routes and its period for the in-plant milk run system. Akillioglu et al. [18] proposed a mixed integer mathematical model to assign stations to vehicle for in-plant milk-run system. The objectives of this model is to minimize total inventory and distribution costs. Obtaining routes for vehicles are evaluated by using a simulation model, widely. Kilic et al. [7] classified the milk-run distribution system and developed a mathematical model in order to minimize the number of vehicles and the total travelled distance in-plant milk-run system. The most important finding in this study is that using multiple routed milk-run trains are more advantageous than one routed milk-run trains. Kilic and Durmusoglu [19] focused on periodic material delivery in lean production environment. They proposed a mathematical model based on mixed integer linear programming in order to minimize transportation costs and developed a heuristic method since the optimal solution could not be obtained when scale of the problem gets bigger. Satoglu and Sipahioglu [10] considered in-plant milk-run routing problem as a cyclic inventory routing problem and developed two assignment based mathematical model for just in time material supply system of the assembly lines. One of the proposed mathematical model is a two-stage approach and another is alternative mixed integer mathematical model. The two-stage approach does not guarantee obtaining the global optimum solution, while alternative model guarantees the global optimum. However, alternative mathematical model performs worse than the other model according to computation time. Mao et al. [20] investigated collecting automobile parts by integrating the progress-lane into the corresponding vehicle routing problem. The related problem is introduced to the literature as "Milk-run routing problem with progress lane (MRPPL)". They proposed a mixed integer linear programming model for small scale instances and genetic algorithm for large scale instances. Computational results show that the use of progress-lane in milk-run system could significantly decrease the total costs. Buyukozkan et al. [21] focused on in-plant milk-run system application in white goods industry. To maintain the assembly lines'operations, they proposed a mathematical model for single-vehicle milk-run system and a matheuristic algorithm for multi-vehicle case.

In this study, in-plant milk-run system is investigated. Milk-run routes and periods must be obtained to operate the system effectively. However, a challenging problem arises in the determination of milk-run routes and periods. Related problem can be explained as obtaining milk-run routes and periods for the AGVs with the minimum total cost to satisfy the demand of assembly stations in cyclic manner.

To contribute to the literature, obtaining optimal in-plant milkrun routes and period in-plant milk-run system, a new mixed integer mathematical model as an exact solution method is developed in this study. The main contribution is that it allows split deliveries for stations and increase vehicle capacity by adding trailers. Moreover, the proposed mathematical model has a different perspective with regard to modelling. Accordingly, the proposed model has less number of constraints and quite short computational time to obtain the optimal solution.

The remainder of this paper has the following structure. In Section 2, proposed Mixed Integer Mathematical Model is presented. In Section 3, computational results of generated test problems are discussed. Finally, conclusion and future work are presented in Section 4.

\section{Proposed mathematical model}

The proposed mathematical model has some assumptions given below.

- The demand of the stations and the capacities of vehicles are known,

- Demand of assembly stations can be splitted,

- Shortage in any assembly station is not allowed,

- There are a limited number of vehicles and trailers on hand,

- Each route starts and ends at single warehouse,

- There is a predetermined path that each AGV has to follow but does not need to serve every assembly station. 
In the proposed model, heterogeneous AGVs can be used. In this regard, additional trailers can be added to each AGV may also have different usage cost. Therefore, the cost of using additional trailers may vary based on the AGV used.

It is necessary to determine a path for AGVs in a plant with $\mathrm{n}$ assembly stations, as they cannot go to each station due to facility layout. This path to be followed by each AGV can be called a predetermined path. The proposed mathematical model enables both the determination of this path namely milkrun routes and its period for each AGV by following the predetermined path, simultaneously. AGVs usage cost, the capacity of AGVs and the total number of AGVs should be considered since there can be different AGVs used. Besides, the entire demand of each assembly station cannot be satisfied by a single AGV. Therefore, split deliveries are allowed for each station in this model.

Each AGV has a certain capacity. However, it is possible to increase the capacity of AGV by multiples of 100 up to 600 units with additional trailers. The proposed model determines which kind of and how many trailers should be added to AGVs. In addition, the possible visiting periods that are available to AGVs are predetermined and demands of the assembly stations are calculated in accordance with these periods. For example, if 60 minutes' period is selected for an assembly station that requires 50 containers (materials) in 30 minutes, demand value of this station is considered 100 containers (materials).

The proposed model is presented below.

Sets:

$i, j:$ Sets of stations $i=\{1,2, \ldots, n\}$

$k$ : Set of $A G V s ; \quad k=\{1,2, \ldots, m\}$

$h$ : Set of additional trailer types; $h=\{1,2, \ldots, \mathrm{H}\}$

$l$ : Set of periods; $l=\{1,2, \ldots, L\}$

Parameters:

$f_{k}$ : Cost of per using AGV $k(\$)$

$q_{k}$ : Capacity of AGV $k$ (containers) (own capacity)

$e_{k}$ : Unit material handling cost of AGV $k$ (\$/meter)

$r_{i}$ : Distance between station ( $i$ )and station $(i+1)$ (meters)

r0: Distance between warehouse and station 1 (meters)

$p_{l}$ : Duration of the period l (min.)

$\left(p_{1}=40 ; p_{2}=60 ; p_{3}=80 ; p_{4}=100\right)$

$d_{i l}$ : Demand of station $i$ during period l (containers)

$a_{h}$ : Capacity of additional trailer $h$ (containers)

$\left(a_{1}=100 ; a_{2}=200 ; a_{3}=300\right)$

$g_{h}$ : Number of additional trailers of type $h$

$b_{k h}$ : Cost of per using additional trailer $h$ in AGV $k(\$)$

hmax: Max. total number of additional trailers for each AGV tmax: Max.number of additional trailer type available for each $A G V$

Decision Variables:

$x_{k l}= \begin{cases}1, & \text { if } A G V k \text { is used at period } l \\ 0, & \text { otherwise }\end{cases}$

$s_{l}= \begin{cases}1, & \text { if period lis used } \\ 0, & \text { otherwise }\end{cases}$
$C_{l}$ : Total cost per minute that corresponds to visiting period $l$ $t_{k h l}=$ Numbers of type $h$ trailer used for AGV $k$ at period $l$ $w_{k l}=$ Total amount of containers for AGV $k$ at period $l$ $y_{i k l}=$ The percentage of satisfying the demand of station $i$ for AGV $k$ at period $l$

$v_{i k l}=$ Amount of containers for AGV $k$ in station $i$

at period $l$

$u=$ Maximum value of obtained cost in each period

Model Formulation:

$$
\min \left\{\max \left(C_{l}\right)\right\}
$$

s.t.

$$
\begin{aligned}
& \sum_{k} y_{i k l}=1 \quad \forall i, l \\
& \sum_{k} x_{k l} \leq m \quad \forall l \\
& y_{i k l} \leq x_{k l} \quad \forall i, k, l \\
& w_{k l}=\sum_{i} d_{i l} * y_{i k l} \quad \forall k, l \\
& w_{k l} \leq x_{k l} * q_{k}+\sum_{h} t_{k h l} * a_{h} \quad \forall k, l \\
& v_{i k l}=w_{k l}-\sum_{j \mid(j \leq i+1)} y_{j k l} * d_{j l} \quad \forall i, k, l \\
& \sum_{l} s_{l}=1 \\
& C_{l}=\left\{\left(\begin{array}{c}
\sum_{k} x_{k l} * f_{k} \\
+\sum_{k} w_{k l} * e_{k} * r_{0} \\
+\sum_{i} \sum_{k} v_{i k l} * e_{k} * r_{i} \\
+\sum_{k} \sum_{h} b_{k h} * t_{k h l}
\end{array}\right) / p_{l}\right\}-\left(M *\left(1-s_{l}\right)\right) \quad \forall l \\
& \sum_{k} t_{k h l} \leq g_{h} \quad \forall h, l \\
& \sum_{h} t_{k h l} \leq h \max \quad \forall k, l \\
& t_{k h l} \leq t \max \quad \forall k, h, l \\
& x_{k l} \in\{0,1\}, s_{l} \in\{0,1\}, w_{k l} \geq 0 \text {, } \\
& y_{i k l} \geq 0, v_{i k l} \geq 0, u \geq 0, t_{k h l} \geq 0 \text { and integer }
\end{aligned}
$$

In this model, the objective function minimizes the maximum total cost per minute to be obtained in period l. Total cost includes vehicle (AGV and additional trailer) usage cost and material handling cost. Please note that this function is minimax then it should be linearized. Constraint (1) states demand of each station must be satisfied by using AGVs at each period. Constraint (2) ensures that the total number of AGVs used is 
limited by the total number of AGVs on hand. Constraint (3) expresses the relationship between $x_{k l}$ and $y_{i k l}$ decision variables. That is to say if an AGV serves any station, the related AGV is used. Constraint (4) represents the total amount of goods in each AGV at each period. Constraint (5) prevents the amount of goods handled by the AGV from exceeding its capacity. This constraint also permits the AGV's capacity to be increased with additional trailer. Constraint (6) indicates the amount of goods in the AGV at each station. This amount is reduced as long as AGV serves the stations. Since the material handling cost depends on the amount of goods in the AGV at each distance, this constraint is used. Constraint (7) ensures only one period is selected among predetermined periods. Accordingly, constraint (8) states that the total cost per minute in period l. Constraint (9) indicates the total number of additional trailers used is limited by the total number of additional trailers on hand, at each period. Constraint (10) and (11) state the number of additional trailers and additional trailer type used are bounded by the upper-bound values for each AGV at each period. Constraint (12) is the sign constraints.

In order to linearize the objective function, transformation given below can be used.

$$
\operatorname{Min} Z=u
$$

s.t.

constraint (1); (2); (3); (4); (5); (6); (7); (8); (9); (10);

$$
\text { (11); (12) }
$$

$$
u \geq C_{l} \quad \forall l
$$

In this model the number of decision variables is $(2 . L+2 . m . L+2 . m . n . L+m . H . L+1)$ and the number of constraints is (3.m.L+m.H.L+H.L+n.L+3.L+2.n.m.L+2)

In this model, using the predetermined path means that each AGV has to follow this path, because of layout structure but does not need to serve each assembly station. That's why, a single index distance parameter $\left(r_{i}\right)$ was proposed for AGVs following the predetermined path. For instance, $r_{2}$ states the distance between second and third station. However, it can also be described in two indices as $r_{i j}$. In this case, $r_{23}$ indicates the distance between second and third station.

\section{Computational results}

Two different test instances are generated to evaluate the performance of the proposed mathematical model. The first instance has 20 assembly stations and the second one has 50 assembly stations. A visual representation of generated test instance having 20 assembly stations is shown in Figure 2.

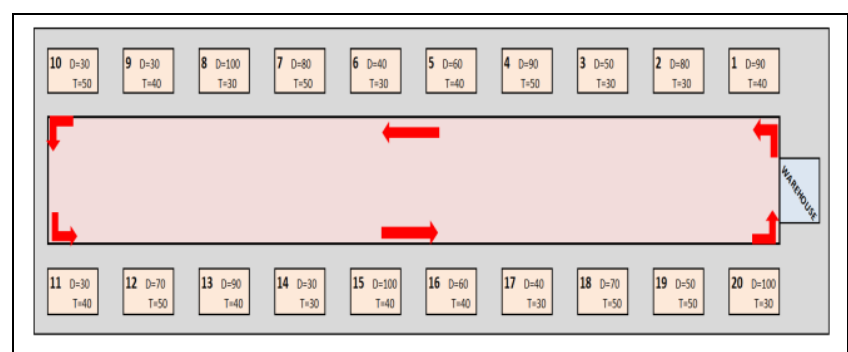

Figure 2: Representation of layout and predetermined path.

The predetermined path is indicated with arrows. That means all AGVs should follow the direction shown in Figure 2. Please note that, the real layout does not have to be as shown. This representation demonstrates the configuration of assembly stations along the predetermined path.

There are 5 heterogeneous AGVs available in this instance. Capacity, usage cost and unit material handling cost of these AGVs are denoted in Table 1. Capacity and usage cost of additional trailer are denoted in Table 2 . Costs are assumed as a monetary unit and capacities and demands are assumed as a weight unit.

In test problems, tmax $=1, \operatorname{hmax}=3$ and $g_{h}=9$. That means maximum only 1 addional trailer type is added to an AGV. Maximum total number of additonal trailers is 3 for an AGV. And there are 9 additional trailer on hand.

Table 1: AGV properties.

\begin{tabular}{cccc}
\hline AGV & $\begin{array}{c}\text { Capacity }\left(q_{k}\right) \\
\text { (containers) }\end{array}$ & $\begin{array}{c}\text { Usage Cost } \\
\left(f_{k}\right) \\
(\$)\end{array}$ & $\begin{array}{c}\text { Unit Material } \\
\text { Handling Cost }\left(e_{k}\right) \\
(\$ / \text { meter })\end{array}$ \\
\hline AGV 1 & 400 & 1400 & 0.05 \\
AGV 2 & 300 & 1600 & 0.011 \\
AGV 3 & 550 & 1300 & 0.08 \\
AGV 4 & 250 & 1500 & 0.09 \\
AGV 5 & 300 & 1200 & 0.07 \\
\hline
\end{tabular}

Table 2: Additional trailer properties.

\begin{tabular}{ccc}
\hline Additional Trailer & $\begin{array}{c}\text { Capacity }\left(a_{h}\right) \\
\text { (containers) }\end{array}$ & $\begin{array}{c}\text { Usage Cost }\left(b_{k h}\right) \\
(\$)\end{array}$ \\
\hline T 1 & 100 & 50 \\
T 2 & 200 & 75 \\
T 3 & 300 & 100 \\
\hline
\end{tabular}

Each assembly station has certain demand for different periods, which are shown in Table 3, and demands should be satisfied, on time. For example, while station- 1 requires 90 containers (materials) every 40 minutes, station- 2 requires 80 containers (materials) every 30 minutes.

Table 3: Demand and period of stations.

\begin{tabular}{cccccc}
\hline Station & $\begin{array}{c}\text { Demand } \\
\text { (containers) }\end{array}$ & $\begin{array}{c}\text { Period } \\
\text { (min.) }\end{array}$ & Station & $\begin{array}{c}\text { Demand } \\
\text { (containers) }\end{array}$ & $\begin{array}{c}\text { Period } \\
\text { (min.) }\end{array}$ \\
\hline 1 & 90 & 40 & 11 & 30 & 40 \\
2 & 80 & 30 & 12 & 70 & 50 \\
3 & 50 & 30 & 13 & 90 & 40 \\
4 & 90 & 50 & 14 & 30 & 30 \\
5 & 60 & 40 & 15 & 100 & 40 \\
6 & 40 & 30 & 16 & 60 & 40 \\
7 & 80 & 50 & 17 & 40 & 30 \\
8 & 100 & 30 & 18 & 70 & 50 \\
9 & 30 & 40 & 19 & 50 & 50 \\
10 & 30 & 50 & 20 & 100 & 30 \\
\hline
\end{tabular}

Based upon in Table 3, the amount of materials required by each station for the predetermined periods are calculated and shown in Table 4. As an example, for 40 min. period station-1 requires 90 containers, station- 2 requires 107 containers, station- 3 requires 67 containers. In this instance, 4 different scenarios with 40,60, 80 and 100 minutes periods are generated. By calculating, demand of station-1 is obtained as 90, 135, 180 and 225 at these scenarios, respectively. All calculated demands are presented in Table 4. 
Table 4: Demand of stations for different scenarios.

\begin{tabular}{ccccccc}
\hline Station & $\begin{array}{c}\text { Demand } \\
\text { (containers) }\end{array}$ & Period & $\begin{array}{c}\text { Scenario 1 } \\
4 \text { min. } \\
\text { Period } \\
\left(d_{i 1}\right)\end{array}$ & $\begin{array}{c}\text { Scenario 2 } \\
60 \text { min. } \\
\text { Period } \\
\left(d_{i 2}\right)\end{array}$ & $\begin{array}{c}\text { Scenario 3 } 3 \\
80 \text { min. } \\
\text { Period } \\
\left(d_{i 3}\right)\end{array}$ & $\begin{array}{c}\text { Scenario } 4 \\
100 \text { min. } \\
\text { Period } \\
\left(d_{i 4}\right)\end{array}$ \\
\hline 1 & 90 & 40 & 90 & 135 & 180 & 225 \\
2 & 80 & 30 & 107 & 161 & 214 & 268 \\
3 & 50 & 30 & 67 & 101 & 134 & 168 \\
4 & 90 & 50 & 72 & 108 & 144 & 180 \\
5 & 60 & 40 & 60 & 90 & 120 & 150 \\
6 & 40 & 30 & 53 & 80 & 106 & 133 \\
7 & 80 & 50 & 64 & 96 & 128 & 160 \\
8 & 100 & 30 & 133 & 200 & 266 & 333 \\
9 & 30 & 40 & 30 & 45 & 60 & 75 \\
10 & 30 & 50 & 24 & 36 & 48 & 60 \\
11 & 30 & 40 & 56 & 84 & 112 & 140 \\
12 & 70 & 50 & 53 & 80 & 106 & 133 \\
13 & 90 & 40 & 40 & 60 & 80 & 100 \\
14 & 30 & 30 & 90 & 135 & 180 & 225 \\
15 & 100 & 40 & 60 & 90 & 120 & 150 \\
16 & 60 & 40 & 100 & 150 & 200 & 250 \\
17 & 40 & 30 & 56 & 84 & 112 & 140 \\
18 & 70 & 50 & 53 & 80 & 106 & 133 \\
19 & 50 & 50 & 133 & 200 & 266 & 333 \\
20 & 100 & 30 & 40 & 60 & 80 & 100 \\
\hline
\end{tabular}

Based upon the given parameters, the proposed mathematical model was solved by the GAMS optimization software's CPLEX solver with personal computer having Intel Core i7-5700HQ CPU and 16 GB RAM. The optimum solution can be found in approximately 1 second. According to solution report, the total cost per minute is equal to 85.59 monetary unit (\$) and there are 3 AGVs (number 1, 2 and 5) and 3 types of additional trailers were used. The service period was obtained as 80 minutes. The results are summarized in Table 5.

Table 5:Summarized results of test problem with $n=20$.

\begin{tabular}{cccc}
\hline $\begin{array}{c}\text { Chosen } \\
\text { Period }\end{array}$ & $\begin{array}{c}\text { \# AGV } \\
\text { Used }\end{array}$ & $\begin{array}{c}\text { Added Trailer } \\
\text { Capacity } \\
\text { (containers) }\end{array}$ & $\begin{array}{c}\text { AGV Routes (\# of assembly } \\
\text { stations)and } \\
\text { The Percentage of Satisfying Demand }\end{array}$ \\
\hline & 1 & 600 & $6(0.34)-7-8-9-10-11-12-13-$ \\
$14(0.91)$ \\
$\begin{array}{c}\text { Scenario 3 } \\
80 \text { min. }\end{array}$ & 2 & 600 & $14(0.09)-15-16-17-18-19-$ \\
Period & 2 & & 20 \\
& 5 & 600 & $1-2-3-4-5-6(0.66)$ \\
\hline
\end{tabular}

In Table 5, the second and third columns show that AGV1, AGV2 and AGV5 are used and 600 unit extra capacity are added for all AGVs. The fourth column shows obtaining AGV routes. These routes denote the number of assembly stations and the percentage of satisfying demand. For example, $34 \%$ of the demand of station- 6 is satisfied by AGV- 1 and the remaining $66 \%$ of the demand of station- 6 is satisfied by AGV-5. \%91 of the demand of station-14 is satisfied by AGV-1 and the remaining $\% 9$ of the demand of station-14 is satisfied by AGV2 . The entire demand of all other stations is satisfied by a single AGV.

The second test problem with 50 assembly stations has been generated in order to show that proposed mathematical model can obtain the optimal solution in short computation time. Moreover, computation time for this test instance was approximately 1 second. On the other hand, the computational complexity of the model have been analyzed on generated large scale test problem which includes 250 stations, 25 AGVs and 3 different additional trailers. Proposed model obtains the optimal solution in 256 seconds for slack capacity constraints and 417 seconds for tight capacity constraints. Sensitivity analysis has been performed on AGV and trailer capacities for the first test problem. The capacity of the AGVs has not been decreased, since tight capacity values are given when generating test problem. For this reason, AGV capacities have remained the same or increased while additional trailer capacities have been increased and decreased. The results of sensitivity analysis are summarized in Table 6.

Table 6:Summarized results of sensitivity analysis.

\begin{tabular}{ccc}
\hline $\begin{array}{c}\text { AGV Capacity } \\
\text { (containers) }\end{array}$ & $\begin{array}{c}\text { Additional Trailer } \\
\text { Capacity } \\
\text { (containers) }\end{array}$ & $\begin{array}{c}\text { Chosen } \\
\text { Period }\end{array}$ \\
\hline AGV 1 (800) & T 1 (200) & \\
AGV 2 (600) & T 2 (400) & 100 minutes \\
AGV 3 (1100) & T 3 (600) & \\
AGV 4 (500) & & \\
AGV 5 (600) & & \\
AGV 1 (800) & T 1 (50) & \\
AGV 2 (600) & T 2 (100) & \\
AGV 3 (1100) & T 3 (150) \\
AGV 4 (500) & \\
AGV 5 (600) & \\
AGV 1 (400) & & \\
AGV 2 (300) & T 1 (200) \\
AGV 3 (550) & T 2 (400) \\
AGV 4 (250) & T 3 (600) \\
AGV 5 (300) & & \\
\hline
\end{tabular}

In Table 6, when capacity amounts of AGVs and trailers are used twice as much as a given value, the model choose the fourth scenario (100 minutes' period). In contrast, when the capacity of AGVs is not changed and trailer capacity is doubled, the first scenario (40 minutes' period) is chosen by the model.

\section{Conclusion}

In this study, in-plant milk run which is a delivery system being run with cyclic manner in plants was investigated. A mixed integer mathematical model was proposed to determine milkrun routes and the milk-run period for AGVs. The proposed model allows split deliveries for assembly stations to obtain effective AGV usage in-plant distribution. Besides, the model can reach the optimal solution approximately in 1 second even if the number of assembly stations is 50 and the capacity of AGV and trailers are tight. Computational complexity of the model is analyzed for the generated large-scale test problem including 250 stations, 25 AGVs and 3 additional trailers. It was found that the proposed model was successful in obtaining the optimal solution in short computation time. By using this model, it is possible to obtain AGV routes on the predetermined path. These routes can intersect with each other due to splitting demand of a station. It causes effective AGV usage. Another contribution is determining the milk-run period by the model among given predetermined periods. 
In the future studies, mathematical model can be extended by adding new constraints to obtain milk-run period instead of predetermined ones for each AGV. In fact, it is also possible to acquire different milk-run periods for each AGV. Moreover, route for each AGV can be obtained by generating various predetermined paths.

\section{References}

[1] Kulak 0. "A decision support system for fuzzy multiattribute selection of material handling equipments". Expert systems with applications, 29(2), 310-319, 2005.

[2] Sule DR. Manufacturing Facilities: Location, Planning and Design. $2^{\text {nd }}$ edition, Boston, USA, PWS Publishing Company, 1994.

[3] Green JC, Lee J, Kozman TA. "Managing lean manufacturing in material handling operations". International Journal of Production Research, 48(10), 2975-2993, 2010.

[4] Nagy G, Salhi S. "Heuristic algorithms for single and multiple depot vehicle routing problems with pickups and deliveries". European journal of operational research, 162(1), 126-41, 2005

[5] Wronka A. "Lean logistics". Journal of Positive Management, 7(2), 55-63, 2016.

[6] Baudin M. Lean logistics: The Nuts and Bolts of Delivering Materials and Goods. New York, USA, Productivity Press, 2005.

[7] Kilic HS, Durmusoglu MB, Baskak M. "Classification and modeling for in-plant milk-run distribution systems". The International Journal of Advanced Manufacturing Technology, 62(9-12), 1135-1146, 2012.

[8] Patel D, Patel MB. "Design and development of an internal milk-run material supply system in automotive industry". International Journal of Application or Innovation in Engineering@Management, 2(8),233-235, 2013.

[9] Ji-li K, Guo-zhu J, Cui-ying G. "A new mathematical model of vehicle routing problem based on milk-run". International Conference on Management Science and Engineering 20th Annual Conference, Harbin, China, 17-19 July 2013.

[10] Satoğlu SI, Sipahioglu A. “An Assignment Based Modelling Approach For The Inventory Routing Problem Of Material Supply Systems Of The Assembly Lines". Sigma: Journal of Engineering \& Natural Sciences/Mühendislik ve Fen Bilimleri Dergisi, 36(1), 161-177, 2018.

[11] You Z, Jiao Y. "Development and application of milk-run distribution systems in the express industry based on saving algorithm". Mathematical Problems in Engineering, 2014, 1-6, 2014.
[12] Gyulai D, Pfeiffer A, Sobottka T, Váncza J. "Milkrun vehicle routing approach for shop-floor logistics". Procedia CIRP, 7, 127-32, 2013.

[13] Brar GS, Saini G. "Milk run logistics: literature review and directions". World Congress on Engineering, London, United Kingdom, 06-08 July 2011.

[14] Eroglu DY, Rafele C, Cagliano AC, Sevilay MS, Ippolito M. "Simultaneous routing and loading method for milk-run using hybrid genetic search algorithm". XII International Logistics and Supply Chain Congress, Istanbul, Turkey, 30-31 October 2014.

[15] Knez M, Gajsek B. "Implementation of in-plant milk-run systems for material supply in lean automotive parts manufacturing". International Conference on Logistics and Sustainable Transport, Celje, Slovenia, 11-13 June 2015.

[16] Duinkerken MB, Ottjes JA, Lodewijks G. "Comparison of routing strategies for AGV systems using simulation". $38^{\text {th }}$ conference on Winter simulation, Monterey, USA, 03-06 December 2006.

[17] Sadjadi SJ, Jafari M, Amini T. "A new mathematical modeling and a genetic algorithm search for milk run problem (an auto industry supply chain case study)". The International Journal of Advanced Manufacturing Technology, 44(1-2), 194-200, 2009.

[18] Akillioglu H, Baydogan MG, Bolatli Y, Canbaz D, Halici A, Sezgin 0, Ozdemirel NE, Turkcan A. "Dizel enjektör üretimi yapan bir şirket için fabrika içi çekme esasli tekrarli dağitim sistemi tasarımı". Endüstri Mühendisliği Dergisi, 17(3), 2-15, 2006.

[19] Kilic HS, Durmusoglu MB. "A mathematical model and a heuristic approach for periodic material delivery in lean production environment". The International Journal of Advanced Manufacturing Technology, 69(5-8), 977-92, 2013.

[20] Mao Z, Huang D, Fang K, Wang C, Lu D. "Milk-run routing problem with progress-lane in the collection of automobile parts". Annals of Operations Research, 282(1-2), 1-28, 2019.

[21] Buyukozkan K, Bal A, Oksuz MK, Kapukaya EN, Satoglu SI. A Mathematical Model and a Matheuristic for In-Plant MilkRun Systems Design and Application in White Goods Industry. Editors: Calisir F, Camgoz Akdag H, Cevikcan E. In Industrial Engineering in the Big Data Era, 99-112, Cham, Switzerland, Springer, 2019. 